\title{
EFEKTIVITAS DAUN KATUK TERHADAP KECUKUPAN AIR SUSU IBU (ASI) PADA IBU MENYUSUI DI BIDAN PRAKTEK MANDIRI (BPM) BD. HJ. IIN SOLIHAH S.ST., KABUPATEN MAJALENGKA
}

\author{
${ }^{1}$ Suyanti, ${ }^{2}$ Kiki Anggraeni \\ ${ }^{1,2}$ STIKes YPIB Majalengka \\ ynt_agst@yahoo.co.id
}

\begin{abstract}
Abstrak
Bayi yang lahir sangat memerlukan makanan yang bergizi yaitu Air Susu Ibu (ASI). Untuk meningkatkan kecukupan ASI dapat dilakukan dengan mengkonsumsi daun katuk. Persentase ASI eksklusif di BPM Bd. Hj. Iin Solihah, S.ST. tahun 2018-2019 masih rendah dan mengalami penurunan sebesar $0,24 \%$, walaupun penurunanya relatif kecil perlu dilakukan upaya untuk meningkatkan kecukupan ASI pada ibu menyusui. Penelitian ini bertujuan untuk mengetahui efektivitas daun katuk terhadap kecukupan ASI pada ibu menyusui di Bidan Praktek Mandiri (BPM) Bd. Hj. Iin Solihah, S.ST., Kabupaten Majalengka Tahun 2020. Jenis penelitian ini quasi eksperimental dengan desain nonequivalent control group design. Sampel dalam penelitian ini adalah 30 orang yang terdiri dari 15 kelompok eksperimen dan 15 kelompok kontrol. Dilakukan pada bulan Maret-Juni 2020. Pengumpulan data menggunakan lembar observasi. Analisis univariat menggunakan distribusi tendensi sentral dan analisis bivariatnya menggunakan uji $\mathrm{t}$ berpasangan. Hasil penelitian menunjukkan bahwa rata kecukupan air susu ibu pada ibu menyusui kelompok eksperimen sebelum pemberian daun katuk sebesar 6,80 dan sesudah pemberian daun katuk 8,47. Kesimpulan pemberian daun katuk terbukti efektif terhadap kecukupan Air Susu Ibu (ASI) pada ibu menyusui.
\end{abstract}

Kata Kunci $\quad$ : Daun Katuk, Air Susu Ibu (ASI), Ibu Menyusui

\section{Pendahuluan}

Generasi yang sehat, cerdas dan berkualitas sebuah bangsa akan ditentukan oleh kesehatan ibu yang melahirkan dan merawat anak-anaknya. Sehingga kesehatan ibu menjadi masalah yang mendapatkan prioritas bagi setiap bangsa termasuk bangsa Indonesia, karena masih banyak masalah 
JOURNAL OF MIDWIFERY CARE :

VOL. 01 NO. 01, DESEMBER 2020

DOI:10.34305/jmc.v1i1.190

yang yang harus diatasi mulai dari masa kehamilan, persalinan, masa nifas dan bayi baru lahir (Kementerian Pemberdayaan Perempuan, 2018).

Bayi yang lahir sangat memerlukan makanan yang bergizi yaitu Air Susu Ibu (ASI). ASI merupakan makanan paling cocok bagi bayi untuk memenuhi kebutuhan gizi dan melindunginya dalam melawan kemungkinan serangan penyakit. Untuk bayi hingga usia enam bulan, ASI sudah mencukupi kebutuhan karbohidrat, lemak, protein, vitamin, dan antibodi yang tidak dimiliki susu formula merk apapun (Roesli, 2012).

Pemberian ASI secara eksklusif menurut World Health Organization (WHO) adalah memberikan hanya ASI saja tanpa memberikan makanan dan minuman lain kepada bayi sejak lahir sampai berumur 6 bulan, kecuali obat dan vitamin. Namun bukan berarti setelah pemberian ASI eksklusif pemberian ASI dihentikan, akan tetapi tetap diberikan kepada bayi sampai bayi berusia 2 tahun (WHO, 2018).

Berdasarkan Profil Kesehatan Indonesia tahun 2018, secara nasional persentase bayi baru lahir yang mendapat ASI eksklusif sebesar $68,74 \%$ dari target nasional sebesar $80 \%$ (Kementerian
Ciptaan disebarluaskan di bawah Lisensi Creative Commons Atribusi-NonKomersialBerbagiSerupa 4.0 Internasional

Kesehatan RI, 2019). Adapun Cakupan ASI eksklusif di Provinsi Jawa Barat pada tahun 2018 sebesar 90,79\%. Meskipun sudah mencapai target, namun masih terdapat beberapa Kabupaten/Kota di Provinsi Jawa Barat yang masih rendah cakupannya, salah satunya Kabupaten Majalengka (Dinas Kesehatan Provinsi Jawa Barat, 2019).

Berdasarkan data Dinas Kesehatan Kabupaten Majalengka pada tahun 2018, cakupan ASI eksklusif di Kabupaten Majalengka sebanyak 15.861 bayi $(75,39 \%)$ dari jumlah keseluruhan sebanyak 21.064 bayi. Cakupan ini belum mencapai target rencana strategis (renstra) $(80 \%)$ (Dinas Kesehatan Kabupaten Majalengka, 2019). Salah satu puskesmas di Kabupaten Majalengka pada tahun 2018 dengan cakupan ASI eksklusif paling rendah terdapat di UPTD Puskesmas Kertajati yaitu sebanyak 207 bayi (22,00\%) dari jumlah bayi sebanyak 941 bayi (Dinas Kesehatan Kabupaten Majalengka, 2019). Cakupan ASI eksklusif di UPTD Puskesmas Kertajati ini paling rendah dan masih jauh dari target yang diharapkan $80 \%$.

Salah satu Bidan Praktek Mandiri (BPM) yang berada di wilayah kerja UPTD Puskesmas Kertajati yang akan dijadikan lokasi oleh peneliti adalah BPM Bd. Hj. Iin 
JOURNAL OF MIDWIFERY CARE :

VOL. 01 NO. 01, DESEMBER 2020

DOI:10.34305/jmc.v1i1.190
Ciptaan disebarluaskan di bawah

Lisensi Creative Commons

Atribusi-NonKomersial-

BerbagiSerupa 4.0 Internasional.
Solihah, S.ST. Berdasarkan data dari BPM

Bd. Hj. Iin Solihah, S.ST., jumlah ibu nifas dan menyusui pada tahun 2018 sebanyak 176 orang dan tahun 2019 sebanyak 160 orang. Menurut Bd. Hj. Iin Solihah, S.ST, beberapa kendala ibu tidak menyusui di BPM Bd. Hj. Iin Solihah, S.ST disamping karena produksi ASI yang kurang ditandai ASI yang keluar sedikit juga dikarenakan faktor kesibukan pekerjaan ibu diantaranya ada yang bekerja di pabrik membantu suami di sawah dan ada yang ikut berdagang atau berjualan.

Salah satu upaya untuk memperbanyak ASI yaitu dengan meningkatkan kualitas makanan yang dapat merangsang pengeluaran ASI, misalnya sayur-sayuran hijau, daun katuk, daun ubi jalar, daun pepaya dan sebagainya (Suraatmaja, 1997). Daun katuk adalah sejenis sayuran daun yang memiliki nama latin Sauropus androgynus dan termasuk famili Euphorbiaceae. Salah satu manfaat daun katuk yang cukup populer adalah kemampuannya untuk memperlancar dan memproduksi ASI (Savitri, 2016).

Untuk meningkatkan kecukupan ASI dapat dilakukan dengan mengkonsumsi daun katuk berupa rebusan atau sayur bening maupun ekstrak daun katuk karena mengandung alkaloid dan sterol yang dapat meningkatkan kelancaran ASI. Selain itu daun katuk mengandung vitamin A, B1, C, tanin, saponin alkaloid papaverin (Rahmanisa, 2015). Daun katuk mengandung hampir $7 \%$ protein dan $19 \%$ serat kasar, vitamin K, pro-vitamin A (beta karoten), Vitamin B dan C. Mineral yang dikandung adalah Kalsium $(2,8 \%)$ zat besi, kalium, fosfor dan magnesium. Daun katuk sudah dikenal oleh nenek moyang kita sebagai sayur pelancar ASI (Savitri, 2016). Pemberian daun katuk dengan cara direbus yaitu diberikan pada ibu menyusui selama 1 minggu ( 7 hari), dikonsumsi oleh ibu pada pagi dan sore dengan dosis sebanyak 50 gram daun katuk direbus dengan air $300 \mathrm{ml}$. Ibu dapat mengkonsumsi rebusan daun katuk ini pada hari ke-2 atau ke-3 setelah melahirkan, hal ini karena peningkatan berat badan bayi pada hari ke-4 dan seterusnya (Apriadi, 2015).

Penelitian yang dilakukan oleh Juliastuti, (2019) mengenai kecukupan ASI pada ibu menyusui di UPTD Puskesmas Tarogong Kabupaten Garut menunjukkan bahwa rebusan daun katuk dan ekstrak daun katuk efektif dalam memenuhi kecukupan ASI. Juga hasil penelitian Nasution, (2019) di Puskesmas Lamepayung Kabupaten 
JOURNAL OF MIDWIFERY CARE :

VOL. 01 NO. 01, DESEMBER 2020

DOI:10.34305/jmc.v1i1.190

Kuningan menunjukkan bahwa pemberian daun katuk efektif untuk produksi ASI pada ibu post partum.

Hasil studi pendahuluan di BPM Bd. Hj. Iin Solihah, S.ST., Kecamatan Kertajati Kabupaten Majalengka pada tanggal 16 Januari 2020, terhadap $10 \mathrm{ibu}$ post partum yang menyusui didapatkan hasil bahwa sebanyak 3 ibu (30\%) mengatakan tidak ada masalah dengan pemberian ASI pada anaknya karena ASI yang keluar cukup banyak, namun 7 ibu (70\%) mengatakan mengalami masalah dengan ASI yaitu 2 orang tidak bisa memberikan ASI pada anaknya dengan alasan sibuk bekerja dan 5 orang (50\%) tidak bisa menyusui karena ASI yang keluar sedikit sehingga ibu di samping memberi ASI juga memberi susu pengganti ASI dan 5 ibu (50\%) tersebut mengatakan belum pernah mengkonsumsi daun katuk untuk mencegah dan meningkatkan ASI.
Ciptaan disebarluaskan di bawah

Lisensi Creative Commons

Atribusi-NonKomersial-

BerbagiSerupa 4.0 Internasional

Berdasarkan latar belakang tersebut, maka peneliti tertarik untuk melakukan penelitian tentang "Efektivitas Daun Katuk terhadap Kecukupan Air Susu Ibu (ASI) Pada Ibu Menyusui di Bidan Praktek Mandiri (BPM) Bd. Hj. Iin Solihah S.ST., Kabupaten Majalengka Tahun 2020.”

\section{Metode}

Jenis penelitian ini merupakan penelitian quasi eksperimental dengan desain nonequivalent control group design. Sampel dalam penelitian ini adalah 30 orang yang terdiri dari 15 kelompok eksperimen dan 15 kelompok kontrol. Dilakukan pada bulan Maret-Juni 2020. Pengumpulan datanya menggunakan lembar observasi. Analisis univariat menggunakan distribusi tendensi sentral dan analisis bivariatnya menggunakan uji t berpasangan.

\section{Hasil}

Tabel 1. Distribusi Tendensi Sentral Kecukupan Air Susu Ibu (ASI) pada Ibu Menyusui yang Diberi dan yang Tidak Diberi Daun Katuk

\begin{tabular}{llllll}
\hline $\begin{array}{l}\text { Kecukupan ASI Sebelum } \\
\text { Pemberian Daun Katuk }\end{array}$ & Mean & Median & S.D & $\begin{array}{l}\text { Minimal- } \\
\text { Maksimal }\end{array}$ & 95\% CI \\
\hline Yang diberi daun katuk & 6,80 & 7,00 & 1,474 & $5-10$ & $5,98-7,62$ \\
Yang tidak diberi daun katuk & 5,80 & 6,00 & 1,421 & $3-8$ & $4,96-6,64$ \\
\hline
\end{tabular}

Berdasarkan tabel 1, menunjukkan bahwa rata-rata kecukupan air susu ibu pada ibu menyusui kelompok eksperimen sebelum pemberian daun katuk sebesar 6,80 
JOURNAL OF MIDWIFERY CARE :

VOL. 01 NO. 01, DESEMBER 2020

DOI:10.34305/jmc.v1i1.190
Ciptaan disebarluaskan di bawah

Lisensi Creative Commons

Atribusi-NonKomersial-

BerbagiSerupa 4.0 Internasional. dengan mediannya 7,00, standar deviasinya 1,474. Paling sedikitnya ibu menyusui 5 kali dalam sehari dan paling banyak 10 kali. Berdasarkan nilai 95\% CI diyakini bahwa kecukupan air susu ibu pada ibu menyusui kelompok eksperimen sebelum pemberian daun katuk di Bidan Praktek Mandiri (BPM) Bd. Hj. Iin Solihah, S.ST., Kabupaten Majalengka Tahun 2020 antara 5,98-7,62. Sedangkan pada kelompok kontrol, rata-rata kecukupan air susu ibu pada hari pertama sebesar 5,80 dengan mediannya 6,00, standar deviasinya 1,421 . Paling sedikitnya ibu menyusui 3 kali dalam sehari dan paling banyak 8 kali. Berdasarkan nilai 95\% CI diyakini bahwa kecukupan air susu ibu pada ibu menyusui kelompok kontrol pada hari pertama di Bidan Praktek Mandiri (BPM) Bd. Hj. Iin Solihah, S.ST., Kabupaten Majalengka Tahun 2020 antara 4,96-6,64.

Tabel 2. Distribusi Tendensi Sentral Kecukupan Air Susu Ibu (ASI) pada Ibu Menyusui yang Diberi dan yang Tidak Diberi Daun Katuk

\begin{tabular}{llllll}
\hline $\begin{array}{l}\text { Kecukupan ASI Sesudah } \\
\text { Pemberian Daun Katuk }\end{array}$ & Mean & $\begin{array}{l}\text { Mean } \\
\text { Median }\end{array}$ & S.D & $\begin{array}{l}\text { Minimal- } \\
\text { Maksimal }\end{array}$ & 95\% CI \\
\hline Yang diberi daun katuk & 8,47 & 8,00 & 1,598 & $6-12$ & $7,58-9,35$ \\
Yang tidak diberi daun katuk & 6,80 & 7,00 & 1,699 & $4-10$ & $5,86-7,74$ \\
\hline
\end{tabular}

Berdasarkan tabel 2, menunjukkan bahwa rata-rata kecukupan air susu ibu pada ibu menyusui kelompok eksperimen sesudah pemberian daun katuk sebesar 8,47 dengan mediannya 8,00, standar deviasinya 1,598. Paling sedikitnya ibu menyusui 6 kali dalam sehari dan paling banyak 12 kali. Berdasarkan nilai 95\% CI diyakini bahwa kecukupan air susu ibu pada ibu menyusui kelompok eksperimen sesudah pemberian daun katuk di Bidan Praktek Mandiri (BPM) Bd. Hj. Iin Solihah, S.ST., Kabupaten Majalengka Tahun 2020 antara 7,58-9,35. Sedangkan pada kelompok kontrol, rata-rata kecukupan air susu ibu pada hari ketujuh sebesar 6,80 dengan mediannya 7,00, standar deviasinya 1,421. Paling sedikitnya ibu menyusui 4 kali dalam sehari dan paling banyak 10 kali. Berdasarkan nilai 95\% CI diyakini bahwa kecukupan air susu ibu pada ibu menyusui kelompok kontrol pada hari ketujuh di Bidan Praktek Mandiri (BPM) Bd. Hj. Iin Solihah, S.ST., Kabupaten Majalengka Tahun 2020 antara 5,86-7,74.

Efektivitas Daun Katuk terhadap Kecukupan Air Susu Ibu (ASI) pada Ibu Menyusui

Sebelum dilakukan analisis dengan uji t, terlebih dahulu dilakukan uji prasyarat terlebih dahulu yaitu dilakukan uji 
JOURNAL OF MIDWIFERY CARE :

VOL. 01 NO. 01, DESEMBER 2020

DOI:10.34305/jmc.v1i1.190
Ciptaan disebarluaskan di bawah

Lisensi Creative Commons

Atribusi-NonKomersial-

BerbagiSerupa 4.0 Internasional. normalitas. Uji normalitas pada penelitian ini menggunakan uji Shapiro Wilk, hal ini karena jumlah respondennya kurang dari 50.
Keputusan ujinya yaitu jika nilai $\mathrm{p}>0,05$ maka data dinyatakan normal dan jika $\mathrm{p}<$ 0,05 .

Tabel 3. Uji Normalitas Data Efektivitas Daun Katuk terhadap Kecukupan Air Susu Ibu (ASI) pada Ibu Menyusui

\begin{tabular}{lcccc}
\hline \multicolumn{1}{c}{ Kecukupan ASI } & \multicolumn{3}{c}{ Shapiro-Wilk } \\
\cline { 2 - 5 } & \multicolumn{2}{c}{ Statistic } & df & Sig. \\
\hline Eksperimen (pretest) & 0.920 & 15 & $0.192^{*}$ \\
Eksperimen (posttest) & 0.928 & 15 & $0.258^{*}$ \\
Kontrol (pretest) & 0.938 & 15 & $0.354^{*}$ \\
Kontrol (posttest) & 0,956 & 15 & $0.624^{*}$ \\
\hline
\end{tabular}

Keterangan: *) berdasarkan Saphiro Wilk

Berdasarkan tabel 3 uji normalitas data dengan Shapiro wilk, menunjukkan bahwa data kecukupan ASI pada kelompok eksperimen sebelum perlakuan (pretest) sebesar 0,192, data kecukupan ASI pada kelompok eksperimen sesudah perlakuan (posttest) sebesar 0,258, data kecukupan ASI pada kelompok kontrol pada hari pertama (pretest) sebesar 0,354 dan data kecukupan ASI pada kelompok kontrol pada hari ketujuh (posttest) sebesar 0,624. Hal ini berarti semua data berdistribusi normal karena nilai $\mathrm{p}>0,05$. Selanjutnya dilakukan uji $\mathrm{t}$ berpasangan dengan hasil sebagai berikut.

Tabel 4. Efektivitas Daun Katuk terhadap Kecukupan Air Susu Ibu (ASI) pada Ibu Menyusui

\begin{tabular}{lccccc}
\hline Kecukupan ASI pada Ibu Menyusui & Mean & $\begin{array}{c}\text { Beda } \\
\text { Mean }\end{array}$ & N & t & P value \\
\hline $\begin{array}{l}\text { Yang diberi daun katuk } \\
- \text { Pretest (hari-1) }\end{array}$ & 6,80 & 1,67 & 15 & 3,851 & 0002 \\
$\begin{array}{l}\text { - Posttest (hari-7) } \\
\text { Yang tidak diberi daun katuk }\end{array}$ & 8,47 & & & & \\
- - Pretest (hari-1) & 5,80 & 1,00 & 15 & 1,345 & 0,200 \\
- Posttest (hari-7) & 6,80 & & & & \\
\hline
\end{tabular}

Keterangan: *) berdasarkan Uji t berpasangan

Berdasarkan tabel 4, menunjukkan bahwa pada kelompok eksperimen rata-rata kecukupan Air Susu Ibu (ASI) pada ibu menyusui sebelum perlakuan sebesar 6,80 dan sesudah perlakuan sebesar 8,47 yang artinya ada selisih sebesar 1,67. Perbedaan ini menunjukkan bahwa daun katuk efektif terhadap kecukupan ASI pada ibu menyusui 
JOURNAL OF MIDWIFERY CARE :

VOL. 01 NO. 01, DESEMBER 2020

DOI:10.34305/jmc.v1i1.190

hal ini dapat dilihat dari nilai $\mathrm{p}=0,002(<$ 0,05). Sedangkan pada kelompok kontrol rata-rata kecukupan ASI pada hari pertama sebesar 5,80 dan sesudah perlakuan sebesar 6,80 yang artinya ada selisih sebesar 1,00. Perbedaan ini menunjukkan bahwa pada kelompok kontrol tidak ada perbedaan kecukupan ASI baik pada hari-1 maupun hari ke-7, hal ini dapat dilihat dari nilai $\mathrm{p}=$ 0,200 (> 0,05). Dengan demikian maka pemberian daun katuk terbukti efektif terhadap kecukupan Air Susu Ibu (ASI) pada ibu menyusui di Bidan Praktek Mandiri (BPM) Bd. Hj. Iin Solihah, S.ST., Kabupaten Majalengka tahun 2020.

\section{Pembahasan}

Gambaran Kecukupan Air Susu Ibu (ASI) pada Ibu Menyusui Sebelum Pemberian Daun Katuk

Berdasarkan hasil penelitian menunjukkan bahwa rata-rata kecukupan air susu ibu pada ibu menyusui kelompok eksperimen sebelum pemberian daun katuk sebesar 6,80. Rata-rata kecukupan air susu ibu ini masih dibawah batas normal yaitu normalnya 8-10 kali dalam sehari, hal ini dapat dikarenakan ibu belum mempersiapkan diri untuk menyusui seperti tidak melakukan perawatan payudara,
Ciptaan disebarluaskan di bawah

Lisensi Creative Commons

Atribusi-NonKomersial-

BerbagiSerupa 4.0 Internasional.

mengkonsumsi makanan yang bernutrisi yang dapat meningkatkan ASI, akibatnya produksi ASI menurun dan menyusui kurang dari batas normal.

Hasil penelitian ini sedikit lebih tinggi dibanding dengan hasil penelitian Juliastuti, (2019) di UPTD Puskesmas Tarogong Kabupaten Garut menunjukkan bahwa sebelum rebusan daun katuk rata-rata ibu menyusui 6,5 kali dalam sehari dan juga lebih tinggi dibanding dengan hasil Nasution, (2019) di Puskesmas Lamepayung Kabupaten Kuningan menunjukkan bahwa sebelum pemberian daun katuk ibu menyusui setiap hari rata-ratanya 6,0 dalam sehari.

Pada hari pertama, biasanya ASI belum keluar, bayi cukup disusukan selama 4-5 menit, untuk merangsang produksi ASI dan membiasakan puting susu dihisap oleh bayi. Setelah hari ke $4-5$, boleh disusukan selama 10 menit. Setelah produksi ASI cukup, bayi dapat disusukan selama 15 menit (jangan lebih dari 20 menit). Menyusukan selama 15 menit ini jika produksi ASI cukup dan ASI lancar keluarnya, sudah cukup untuk bayi. Dikatakan bahwa, jumlah ASI yang terisap bayi pada 5 menit pertama adalah $\pm 112 \mathrm{ml}$, 
JOURNAL OF MIDWIFERY CARE :

VOL. 01 NO. 01, DESEMBER 2020

DOI:10.34305/jmc.v1i1.190

5 menit kedua $\pm 64 \mathrm{ml}$, dan 5 menit terakhir hanya $\pm 16 \mathrm{ml}$ (Roesli, 2012).

Produksi ASI adalah nilai kumulatif berdasarkan apa yang dilihat di lapangan yang dapat diukur dengan menggunakan banyaknya volume ASI yang diminum bayi selama satu hari. Tanda bayi mendapatkan ASI yang cukup adalah bayi minum ASI tiap 2-3 jam atau dalam 24 jam minimal mendapatkan ASI 8-10 kali pada 2-3 minggu pertama, bayi akan buang air kecil (BAK) paling tidak 6-8 kali sehari, berat badan bayi naik 125 gram per minggu dan tidak terjadi penurunan berat bayi lebih dari $7 \%$ dari berat lahir (Susilaningrum, 2016).

Masih terdapatnya ibu dengan kecukupan air susu ibu kurang dari batas normal, maka petugas kesehatan perlu memberikan konseling atau penyuluhan kepada ibu nifas tentang perlunya mengkonsumsi makanan yang bernutrisi dan bisa meningkatkan ASI salah satunya daun katuk. Bagi ibu nifas yang mengalami masalah dengan menyusui perlu mencari informasi tentang daun katuk dan cara mengkonsumsinya agar mengatasi masalahnya.

Gambaran Kecukupan Air Susu Ibu (ASI) pada Ibu Menyusui Sesudah Pemberian Daun Katuk
Ciptaan disebarluaskan di bawah

Lisensi Creative Commons

Atribusi-NonKomersial-

BerbagiSerupa 4.0 Internasional.

Berdasarkan hasil penelitian menunjukkan bahwa rata-rata kecukupan air susu ibu pada ibu menyusui kelompok eksperimen sesudah pemberian daun katuk sebesar 8,47. Kecukupan air susu ibu setelah diberi daun katuk ternyata mengalami kenaikan menjadi 8,47 dari 6,80 hal ini dapat dikarenakan ibu mengkonsumsi daun katuk secara teratur selama seminggu, akibatnya kecukupan air susu ibu meningkat dan frekuensinya dalam batas normal.

Hasil penelitian ini lebih rendah dibanding dengan hasil penelitian yang dilakukan oleh Suwanti \& Kuswati, (2016) di Puskesmas Cibogo Kabupaten Subang menunjukkan bahwa setelah pemberian daun katuk ibu menyusui sebanyak 9,0 per hari. Juga lebih rendah dibanding dengan hasil penelitian Gunanegara et al., (2010) di Puskesmas Jatibarang Kabupaten Indramayu menunjukkan bahwa setelah pemberian daun katuk menjadi 10,0 per hari.

Katuk (Sauropus androgynus) merupakan tanaman obat-obatan tradisional yang mempunyai zat gizi tinggi, sebagai antibakteri, dan mengandung beta karoten sebagai zat aktif warna karkas (Santoso, 2015). Manfaat daun katuk sangat berguna bagi wanita yang sedang menyusui. Sebuah penelitian mengungkapkan, bahwa daun 
JOURNAL OF MIDWIFERY CARE :

VOL. 01 NO. 01, DESEMBER 2020

DOI:10.34305/jmc.v1i1.190

katuk dapat meningkatkan ekspresi gen prolaktin dan oksitosin pada tikus yang menyusui. Perlu diketahui bahwa prolaktin dan oksitosin adalah dua hormon yang mempengaruhi produksi ASI. Selain itu, khasiat daun katuk bagi ibu menyusui juga terkait dengan kandungan galactagogue yang ada di dalamnya. Galactagogue adalah senyawa yang dapat memicu peningkatan produksi ASI (Savitri, 2016).

\section{Efektivitas Daun Katuk terhadap}

Kecukupan Air Susu Ibu (ASI) pada Ibu Menyusui

Berdasarkan hasil penelitian menunjukkan emberian daun katuk terbukti efektif terhadap kecukupan ASI, hal ini dikarenakan daun katuk merupakan salah satu tanaman yang dapat merangsang keluarnya ASI, sehingga ibu yang mengkonsumsi daun katuk setiap pagi dan sore selama seminggu kecukupan ASI nya akan membaik atau meningkat.

Hasil penelitian ini sejalan dengan hasil penelitian yang dilakukan oleh Juliastuti, (2019) pada ibu menyusui di UPTD Puskesmas Tarogong Kabupaten Garut menunjukkan bahwa rebusan daun katuk efektif dalam memenuhi kecukupan ASI, juga sejalan dengan hasil penelitian Suwanti \& Kuswati, (2016) di Puskesmas
Ciptaan disebarluaskan di bawah Lisensi Creative Commons Atribusi-NonKomersialBerbagiSerupa 4.0 Internasional

Cibogo Kabupaten Subang tahun 2016 menunjukkan bahwa ada pengaruh yang signifikan konsumsi pemberian daun katuk terhadap kecukupan ASI $(\mathrm{p}=0,000)$. Demikian juga dengan hasil penelitian Agustina, (2014) di Depok Jawa Barat menunjukkan bahwa pemberian daun katuk dapat meningkatkan jumlah menyusui.

Pemberian daun katuk dengan cara direbus yaitu diberikan pada ibu menyusui selama 1 minggu (7 hari), dikonsumsi oleh ibu pada pagi dan sore dengan dosis sebanyak 50 gram daun katuk direbus dengan air $300 \mathrm{ml}$. Ibu dapat mengkonsumsi rebusan daun katuk ini pada hari ke-2 atau ke-3 setelah melahirkan, hal ini karena peningkatan berat badan bayi pada hari ke-4 dan seterusnya (Apriadi, 2015).

\section{Kesimpulan}

Pemberian daun katuk terbukti efektif terhadap kecukupan Air Susu Ibu (ASI) pada ibu menyusui di Bidan Praktek Mandiri (BPM) Bd. Hj. Iin Solihah, S.ST., Kabupaten Majalengka tahun 2020.

\section{Saran}

Ibu nifas dapat mengkonsumsi daun katuk setiap pagi dan sore hari selama seminggu untuk merangsang keluarnya ASI. 
JOURNAL OF MIDWIFERY CARE :

VOL. 01 NO. 01, DESEMBER 2020

DOI:10.34305/jmc.v1i1.190

Penelitian ini dapat dikembangkan lebih lanjut dengan menambah variabel lain atau desain penelitian yang berbeda

\section{Daftar Pustaka}

Agustina, E. R. (2014). Pengaruh Kombinasi Ekstrak Daun Katuk (Sauropus androgynus (L.) Merr.) dan Domperidon Terhadap Involusi Uterus Mencit Menyusui. Universitas Kristen Maranatha.

Apriadi, S. (2015). Cara Mengolah Daun Katuk Untuk Menyusui. www.hellosehat.com

Dinas Kesehatan Kabupaten Majalengka. (2019). Profil Kesehatan Kabupaten Majalengka tahun 2018. Dinas Kesehatan Kabupaten Majalengka.

Dinas Kesehatan Provinsi Jawa Barat. (2019). Derajat Kesehatan Provinsi Jawa Barat 2018. Dinas Kesehatan Provinsi Jawa Barat.

Gunanegara, R. F., Suryawan, A., Sastrawinata, U. S., \& Surachman, T. (2010). Efektivitas Ekstrak Daun Katuk dalam Produksi Air Susu Ibu untuk Keberhasilan Menyusui. Maranatha Journal of Medicine and Health, 9(2), 151203.

Juliastuti, J. (2019). Efektivitas Daun Katuk (Sauropus Androgynus) Terhadap Kecukupan Asi Pada Ibu Menyusui Di Puskesmas Kuta Baro Aceh Besar. Indonesian Journal for Health Sciences, 3(1), 1-5.

Kementerian Kesehatan RI. (2019). Profil
Ciptaan disebarluaskan di bawah Lisensi Creative Commons Atribusi-NonKomersialBerbagiSerupa 4.0 Internasional

kesehatan Indonesia tahun 2018. Kementerian Kesehatan RI.

Kementerian Pemberdayaan Perempuan. (2018). Profil anak indonesia 2018. Jakarta: Kementerian Pemberdayaan Perempuan Dan Perlindungan Anak.

Nasution, A. N. (2019). Efektifitas Pemberian Simplisia Daun Katuk Terhadap Produksi Asi Pada Ibu Post Partum Di Praktik Mandiri Bidan Afriana, Am. Keb Tahun 2018.

Rahmanisa. (2015). Pengeluaran Asi Pada Ibu Postpartum. Husada Mahakam, III(8).

Roesli, U. (2012). Panduan: inisiasi menyusu dini: plus asi eksklusif. Pustaka Bunda.

Santoso. (2015). Manfaat Daun Katuk Untuk Ibu Menyusui. www.haibunda.com

Savitri, A. (2016). Tanaman Ajaib! Basi Penyakit dengan TOGA (Tanaman Obat Keluarga). Bibit Publisher.

Suraatmaja, S. (1997). Aspek gizi air susu ibu, dalam ASI petunjuk untuk tenaga kesehatan. Soetjiningsih, Editor. Jakarta: EGC.

Susilaningrum. (2016). Asuhan Kebidanan Masa Nifas. Pustaka Media.

Suwanti, E., \& Kuswati, K. (2016). Pengaruh Konsumsi Ekstrak Daun Katuk Terhadap Kecukupan ASI Pada Ibu Menyusui Di Klaten. Interest: Jurnal Ilmu Kesehatan, 5(2).

WHO. (2018). Data Asi Se-dunia. www.who.int 